\title{
The irreversible loss of alanine and of glycine in fetal and sucking lambs
}

\author{
By G. M. HATFIELD,* JENNY JOYCE, MARJORIE K. JEACOCK \\ AND D. A. L. SHEPHERD $†$ \\ Department of Physiology \& Biochemistry, The University, Whiteknights, \\ Reading RG6 $2 A J$
}

(Received 19 September 1983 - Accepted 29 May 1984)

1. Estimates have been made of the irreversible loss of alanine and of glycine in chronically catheterized fetal lambs and in sucking lambs using $\left[\mathrm{U}-{ }^{14} \mathrm{C}\right]$-labelled radioisotopes. The experiments in the fetal lambs were carried out at least $5 \mathrm{~d}$ after implantation of catheters.

2. The mean concentration of glycine in fetal femoral arterial blood between 102 and $129 \mathrm{~d}$ conceptual age was $755 \mu \mathrm{mol} / 1$ and this was not significantly different from that in maternal venous blood. The mean concentration of alanine in fetal femoral arterial blood during the same period of gestation was $229 \mu \mathrm{mol} / 1$ and this was significantly greater than that in maternal venous blood.

3. Assuming a catenary model, the mean irreversible loss of glycine, determined using the single-injection technique, in three fetal lambs of 107,111 and $127 \mathrm{~d}$ conceptual age was $17 \mu \mathrm{mol} / \mathrm{min}$ per $\mathrm{kg}$, whereas in two fetal lambs aged 106 and $109 \mathrm{~d}$ into which the isotope was infused continuously the mean irreversible loss, calculated from the specific activity of glycine $5 \mathrm{~h}$ after the start of infusion of the tracer ('pseudo plateau'), was $12 \mu \mathrm{mol} / \mathrm{min}$ per $\mathrm{kg}$. In a sucking lamb, $9 \mathrm{~d}$ after birth, the irreversible loss of glycine was $11 \mu \mathrm{mol} / \mathrm{min} \mathrm{per} \mathrm{kg}$. The mean irreversible loss of alanine, determined by the single-injection technique assuming a catenary model in five fetuses between 112 and $121 \mathrm{~d}$ conceptual age was $14 \mu \mathrm{mol} / \mathrm{min}$ per $\mathrm{kg}$, and in two sucking lambs, 9 and $11 \mathrm{~d}$ after birth, it was $5.1 \mu \mathrm{mol} / \mathrm{min}$ per $\mathrm{kg}$.

4. When a two-pool model was assumed in which entry of metabolite was not directly into the sampling pool but was by way of the second pool, then the mean irreversible loss of glycine in the three fetuses was $23 \mu \mathrm{mol} / \mathrm{min}$ per $\mathrm{kg}$ and of alanine in the five fetuses was $32 \mu \mathrm{mol} / \mathrm{min}$ per $\mathrm{kg}$. Calculations based on the alternative two-pool model did not alter appreciably the rates of irreversible loss of either alanine or glycine in the sucking lambs.

5. From a comparison of the specific activities of the amino acids and of carbon dioxide in blood during the course of the experiments, it was found that in the fetuses $0.96 \%$ of the $\mathrm{CO}_{2}$ present in blood was derived from alanine and only $0.12 \%$ was derived from glycine. It was calculated that not more than $1.6 \mu \mathrm{mol}$ alanine $/ \mathrm{min}$ per $\mathrm{kg}$ and $0.29 \mu \mathrm{mol}$ glycine $/ \mathrm{min}$ per $\mathrm{kg}$ could have been converted to $\mathrm{CO}_{2}$ in the fetal lambs.

6. It is concluded that since glycine in fetal blood originates from fetal tissues and not from direct transfer across the placenta the upper value for the irreversible loss describes metabolism best. In the case of alanine, which is derived from both the maternal circulation and from metabolism in fetal tissues, the true rate of irreversible loss must lie between the values predicted by the two models.

Amino acids are used for protein synthesis in the ovine fetus. However, the possibility that they may be used for other purposes has been indicated by the observations that fetal lamb liver can synthesize urea (Rattenbury et al. 1980) and that there is a net clearance of urea from fetal blood by way of the placenta (Gresham et al. 1972). These workers have calculated that as much as $25 \%$ of the fetal oxygen consumption near term could be accounted for by the catabolism of amino acids. Hodgson et al. (1980) have suggested that fetal amino acids may provide a major part of the carbon required for the high rate of fetal gluconeogenesis which must occur if glucose of maternal origin accounts for about $70 \%$ of the fetal glucose requirements. However, the contribution of individual amino acids for protein synthesis and other metabolic pathways in the sheep fetus has not been evaluated fully.

The aim of the present study was to estimate the irreversible loss of alanine and of glycine

* Present address: The Computer Unit, Newcastle upon Tyne Polytechnic, Northumberland Building, St Mary's Place, Newcastle upon Tyne NE1 8ST.

$\dagger$ For reprints. 
in the sheep fetus and the proportion of this loss which could be accounted for by oxidation. Glycine is present in ovine blood at a concentration approximately two to three times greater than that of any other amino acid (Lemons et al. 1976) and thus the amino group of glycine represents the largest single fraction of free amino-nitrogen in the circulation which is available for uptake by the tissues. Moreover, of the amino acid 'turnover' rates which have been reported for adult sheep, that for glycine exceeds that of the other amino acids studied so far (Wolff \& Bergman, 1972; Heitman et al. 1973; Egan \& MacRae, 1979). There is also a substantial 'turnover' of alanine in adult sheep and this may be related to the possibility that this amino acid is involved in the interorganal transfer of $\mathrm{N}$ and $\mathrm{C}$ by way of the so-called glucose-alanine cycle (Schepartz, 1973).

\section{MATERIALS AND METHODS}

\section{Chemicals}

$\left[\mathrm{U}-{ }^{14} \mathrm{C}\right]$-labelled radioisotopes of L-alanine and glycine were obtained from Amersham International plc, Amersham, Bucks. L-Alanine dehydrogenase (EC 1.4.1.1), coenzymes and Tris(hydroxymethyl)-amino methane were purchased from Boehringer Corporation (London) Ltd, Lewes, East Sussex; cellulose powder from Whatman Biochemicals Ltd, Maidstone, Kent; Triton X-100 from Koch Light Laboratories Ltd, Colnbrook, Bucks. All other chemicals were supplied by British Drug Houses Chemicals Ltd, Poole, Dorset, or Sigma (London) Chemical Co. Ltd, Poole, Dorset.

\section{Animals}

Fourteen polled Dorset Horn ewes tupped by Suffolk rams on known dates were used. Oestrus was synchronized in groups of ewes using medroxyprogesterone acetate sponges (Upjohn Ltd, Crawley, Sussex). The conceptual age of the fetuses was confirmed by radiological examination at the Grassland Research Institute, Hurley. Animals were transported from the University farms to the Departmental Animal House at least 1 week before surgery. The ewes were penned individually and they were given hay and concentrate (a commercial pelleted ration) twice daily. The amounts offered were such that the amount of metabolizable energy and digestible crude protein $(N \times 6.25)$ were equal to or greater than the recommended allowances (Agricultural Research Council, 1965; Ministry of Agriculture, Fisheries and Food, 1975) considering the weight of the ewe, the stage of pregnancy and the number of fetuses carried. Daily residues, if any, were weighed. The lambs were born indoors, suckled by their mothers and had access to their mother's rations. The weights for the ten fetal lambs were estimated by reference to an equation derived from values accumulated in this laboratory since 1970 :

$$
\text { weight }(\mathrm{kg})=\exp \langle\{\ln [(0.01413 \times \text { age }(\mathrm{d}))-0.42064]\} / 0.33333\rangle \text {. }
$$

The conceptual age of the three sucking lambs was calculated assuming that gestation lasted $147 \mathrm{~d}$.

\section{Surgery}

Ewes were fasted for $24 \mathrm{~h}$ before surgery. The operations were performed on ewes carrying fetuses of between 95 and $110 \mathrm{~d}$ conceptual age. Paravertebral anaesthesia was induced in the ewes using lignocaine hydrochloride ( $20 \mathrm{~g}$ Xylocaine/l; Astra Chemicals Ltd, Watford, Herts). The ewes were sedated throughout the operation with ketamine hydrochloride (Vetalar; Park Davis \& Company Ltd, Pontypool). An initial dose of $200 \mathrm{mg}$ ketamine was injected intravenously and ketamine was then infused into a jugular vein at a rate of $0 \cdot 16 \mathrm{mg} / \mathrm{kg}$ per min. The uterus was exposed through a dorso-ventral incision on the left 
flank $150 \mathrm{~mm}$ posterior to the last rib. A single lumen, clear vinyl cannula (normally i.d. $0.75 \mathrm{~mm}$, o.d. $1.45 \mathrm{~mm}$; Dural Plastics Ltd, Dural, NSW 2158, Australia) was introduced into a uterine vein near the tip of the uterine horn. The cannula was inserted into the vein for approximately $250 \mathrm{~mm}$. The cannula was secured around a cuff on to the uterus using chromic catgut. The uterus and fetal membranes were then opened on the greater curvature of the uterus and the membranes were held to the uterine wall by means of Allis tissue forceps. The hind-limbs of the fetus were exteriorized, care being taken to minimize the loss of fetal fluids. A femoral artery was exposed and a vinyl cannula (normally i.d. $0.5 \mathrm{~mm}, 0 . \mathrm{d} .1 .0 \mathrm{~mm}$ ) was inserted for approximately $100 \mathrm{~mm}$ so that the tip lay in the aorta. The cannula was secured around a cuff with chromic catgut and the wound was repaired. The posterior vena cava was cannulated by way of the recurrent tarsal vein, again using vinyl tubing (i.d. $0.5 \mathrm{~mm}$, o.d. $1.0 \mathrm{~mm}$ ). The fetal umbilical vein was cannulated by way of a cotyledonary tributary with vinyl tubing (i.d. $0.5 \mathrm{~mm}, 0$. d. $1.0 \mathrm{~mm}$ ) in a manner similar to that described by Meschia et al. (1969). The cannula was inserted for up to $300 \mathrm{~mm}$. In cases where fetal limb vessels had been cannulated previously a different uterine site was chosen for access to the placental cotyledons. After cannulas had been secured, the fetal membranes were fixed to the uterine wall with interrupted chromic catgut sutures. A sufficient length of cannula tubing was left within the uterus to allow for fetal movements and the uterine incision was then closed with two rows of continuous catgut sutures. The uterus was replaced within the abdominal cavity and $1.2 \mathrm{~g}$ sodium benzyl penicillin powder (Crystapen; Glaxo Laboratories Ltd, Greenford) was sprinkled into the wound. The abdominal incision was closed with four interrupted monofilament nylon sutures, the cannulas being exteriorized through the upper end of the incision. The cannulas were placed in small sealable polyethylene bags which were secured on to the back of the ewe. All cannulas were then filled with fresh sterilized $0.15 \mathrm{M}$-sodium chloride containing heparin $\left(2 \times 10^{5}\right.$ units $/$, Heparin BP (mucous); Boots Company Ltd, Nottingham) and sodium benzyl penicillin $(6 \mathrm{~g} / \mathrm{l})$ by way of hypodermic needles inserted into the ends of the cannulas which were then capped. The duration of surgery rarely exceeded $2 \mathrm{~h}$.

\section{Assessment of the recovery of animals from operative stress}

In order to determine by what time the animals could be considered 'recovered' after surgery, several indices were measured. From a consideration of the food intake of the ewes, the maternal and fetal packed cell volume, fetal blood $\mathrm{pH}, \mathrm{CO}_{2}$ pressure $\left(\mathrm{pCO}_{2}\right)$ and $\mathrm{O}_{2}$ pressure $\left(\mathrm{pO}_{2}\right)$, and maternal and fetal blood metabolite concentrations, we concluded that the animals could be considered 'recovered' by $5 \mathrm{~d}$ after the implantation of cannulas into the vasculature and that after this time reliable measurements of metabolite concentration and kinetic indices could be made in the blood of conscious, fed, pregnant ewes and their progeny. Hence the values reported here were obtained from animals at least $5 \mathrm{~d}$ after surgery.

The cannulation of a vessel was only deemed successful if blood samples could be obtained with ease at five and more days following the operation. Using this criterion the success rate of the cannulations was as follows: uterine vein 0.5 , fetal femoral artery 0.71 , umbilical vein 0.43 , posterior vena cava 0.43 . In one case (Gly 5 ) the fetus died following the isotope-dilution experiment and therefore the results of this experiment have been discarded.

\section{Sampling and analytical methods}

Ewes were trained to stand quietly in their pens during blood sampling and they were not normally restrained in any way. Cannulas were flushed and refilled daily at 10.00 hours, immediately following the morning feed, with $0.15 \mathrm{M}$-sodium chloride containing heparin 
$\left(2 \times 10^{5}\right.$ units $\left./ 1\right)$ and sodium benzyl penicillin $(6 \mathrm{~g} / 1)$. Blood samples were also taken at this time. For blood sampling the cannulas were initially flushed with $0.5 \mathrm{ml}$ of the sterile heparinized saline solution and blood was drawn back into the syringe which was discarded. Normally $2.5 \mathrm{ml}$ blood was withdrawn into a fresh syringe and placed in a heparinized vial on ice. The cannulas were refilled with heparinized saline solution, recapped and replaced in the bags. Vinyl cannulas filled with the heparinized saline were inserted into the jugular veins of the ewes and of the sucking lambs $1 \mathrm{~d}$ before the isotope experiments. On other occasions blood samples were taken from the jugular veins of ewes using a needle and syringe.

Blood $\mathrm{pO}_{2}, \mathrm{pCO}_{2}$ and $\mathrm{pH}$ were determined using a IL213 blood gas analyser (Instrumentation Laboratories UK Ltd, Altrincham, Cheshire), and the packed cell volume determinations were made using a Super-minor centrifuge fitted with a micro-haematocrit attachment (Measuring and Scientific Equipment Ltd, Crawley, Sussex).

For the analysis of glycine, blood was deproteinized by adding $0.5 \mathrm{ml}$ blood to $4 \mathrm{ml}$ $1 \mathrm{M}$-sulphuric acid. After mixing, $0.5 \mathrm{ml} 0.45 \mathrm{M}$-sodium tungstate was added. The glycine content of the supernatant fraction was determined colorimetrically (Sardesai \& Provido, 1970). For the analysis of alanine, blood was deproteinized by addition of an equal volume of ice-cold 3.5 M-perchloric acid. After neutralization with $4 \mathrm{M}$-potassium hydroxide the alanine content of the supernatant fraction was determined using L-alanine dehydrogenase (Williamson, 1974). For the determination of specific radioactivity, the individual metabolites present in a known volume of the supernatant fractions were first separated by twodimensional thin-layer chromatography on cellulose (Haworth \& Heathcote, 1969). A stripping mixture (Redgwell et al. 1974) was used to enable the detachment of individual amino acid spots from the plates and then the radioactivity of specific compounds was determined by counting in an NE8310 automatic liquid-scintillation spectrometer (Nuclear Enterprises Ltd, Beenham, Berks). The method used for the determination of the specific activity of $\mathrm{CO}_{2}$ (including bicarbonate) in whole blood was similar to that described by Hinks et al. (1966).

\section{Radioisotope experiments}

For the estimations of the rates of irreversible loss, pool sizes and related kinetic indices of the amino acids in fetal and sucking lambs, the single injection technique was used most frequently. The conceptual age, weight and amount of isotope administered to each lamb is given in Table 1. Following injection of [U-14 C]-labelled amino acid, blood samples were withdrawn normally at 2, 5, 10,20,30, 40,60,80,120,180, 240 and 300 min after zero time for the determination of the specific activity of metabolites. Maternal jugular blood and, where possible, uterine venous blood samples were taken at intervals. The fitting of the specific activity $v$. time curve to the experimental values was attempted for up to three exponential terms using a multiple-exponential curve-fitting program based on a least-squares minimization procedure (Ottaway, 1973; Numerical Algorithms Group, 1975). The calculation of metabolite flux rates, rate constants and pool sizes for the models were based on the procedures described by Shipley \& Clark (1972). The product-precursor relationships between blood $\mathrm{CO}_{2}$ and amino acids were calculated using methods given by Shipley \& Clark (1972) and Bergman (1963).

In two experiments the rate of irreversible loss of glycine was estimated using a constant infusion of [U- $\left.{ }^{14} \mathrm{C}\right]$ glycine into the vena cava using a Braun Unita II constant infusion pump (F.T. Scientific Instruments Ltd, Bredon, Tewkesbury, Glos.). Blood samples were taken at 30-min intervals for up to $6 \mathrm{~h}$. Curves were fitted to the values relating specific activity and time and equations were obtained to describe the curves. From these curves it appeared that the 'pseudo'-plateau (Waterlow et al. 1978) had been reached by $5 \mathrm{~h}$ and the specific 
Table 1. Age, weight and amount of isotope administered to each lamb

(The weight of the fetal lambs was calculated as described on p. 530. The conceptual age of the sucking lambs was calculated assuming that gestation lasts for $147 \mathrm{~d}$ in sheep)

\begin{tabular}{|c|c|c|c|c|c|c|}
\hline Amino acid & Experiment & $\begin{array}{l}\text { Conceptual } \\
\text { age (d) }\end{array}$ & $\begin{array}{c}\text { Wt } \\
(\mathrm{kg})\end{array}$ & Type of experiment & $\begin{array}{c}\text { Site of } \\
\text { administration } \\
\text { of isotope }\end{array}$ & $\begin{array}{l}\text { Amount of } \\
\text { isotope } \\
\text { administered } \\
(\mu \mathrm{Ci})\end{array}$ \\
\hline \multirow[t]{6}{*}{ Glycine } & Gly 2 & 106 & $1 \cdot 21$ & Continuous infusion & Vena cava & $1 \cdot 26^{*}$ \\
\hline & Gly 1 & 107 & $1 \cdot 35$ & Single injection & Femoral artery & 160 \\
\hline & Gly 3 & 109 & 1.45 & Continuous infusion & Vena cava & $1 \cdot 19^{*}$ \\
\hline & Gly 4 & 111 & $1 \cdot 51$ & Single injection & Vena cava & 250 \\
\hline & Gly 7 & 127 & $2 \cdot 59$ & Single injection & Umbilical vein & 375 \\
\hline & Gly 6 & 156 & 3.95 & Single injection & Jugular vein & 200 \\
\hline \multirow[t]{7}{*}{ Alanine } & Ala 1 & 112 & 1.57 & Single injection & Umbilical vein & 80 \\
\hline & Ala 6 & 116 & 1.87 & Single injection & Vena cava & 375 \\
\hline & Ala 5 & 118 & 1.90 & Single injection & Umbilical vein & 375 \\
\hline & Ala 7 & 119 & 1.94 & Single injection & Umbilical vein & 375 \\
\hline & Ala 2 & 121 & $2 \cdot 22$ & Single injection & Femoral artery & 150 \\
\hline & Ala 4 & 156 & $3 \cdot 70$ & Single injection & Jugular vein & 300 \\
\hline & Ala 3 & 158 & $7 \cdot 25$ & Single injection & Jugular vein & 160 \\
\hline
\end{tabular}

* $\mu \mathrm{Ci} / \mathrm{min}$.

activity at the 'pseudo'-plateau was determined from the equation rather than from a particular experimental value. The estimate of the rate of irreversible loss of glycine calculated by dividing the rate of isotope infusion by the specific activity of glycine at the 'pseudo'-plateau (Shipley \& Clark, 1972) includes the rate of glycine incorporation into protein.

\section{Model formulation}

Values derived from radioisotope-dilution experiments allow for the formulation of models describing the flow of a particular compound into, out of and between a number of pools. These pools may either be considered as physical locations within the animal, for example blood, the interstitial fluid and intracellular fluid, or as chemical species such as the free amino acid, protein-bound amino acid or a closely-related metabolite such as pyruvate in the case of alanine. In the present study we have made the assumption, as did Waterlow et al. (1978), that the pools describe physical locations rather than chemical species.

In each experiment the fitting of the specific activity $v$. time curve was attempted for up to three exponential terms. In only two cases (Gly 6, Ala 2) did the line described by three exponential functions fit the values significantly better than did the line described by two functions, the probability of goodness of fit being determined from Chi-square distribution tables. We have considered that our results are best described by a two-pool system throughout.

It is possible to construct metabolic models with the number of pools equal to the number of exponential terms. As shown in model 1 (a), Fig. 1, a model based on a two-pool system can exist as entry into (Fao, Fbo) and exit (Foa, Fob) from both pools individually and interchange ( $\mathrm{Fab}, \mathrm{Fba}$ ) between the two pools. If the assumption is made that pool $\mathrm{A}$ and pool $\mathbf{B}$ are physical locations within the animal then pool A, by definition the sampling pool and the one into which the isotope is injected, must include the cellular and extracellular components of blood and possibly the other extracellular fluids. Pool B is taken, therefore, to be the intracellular compartments of other tissues including, in the case 

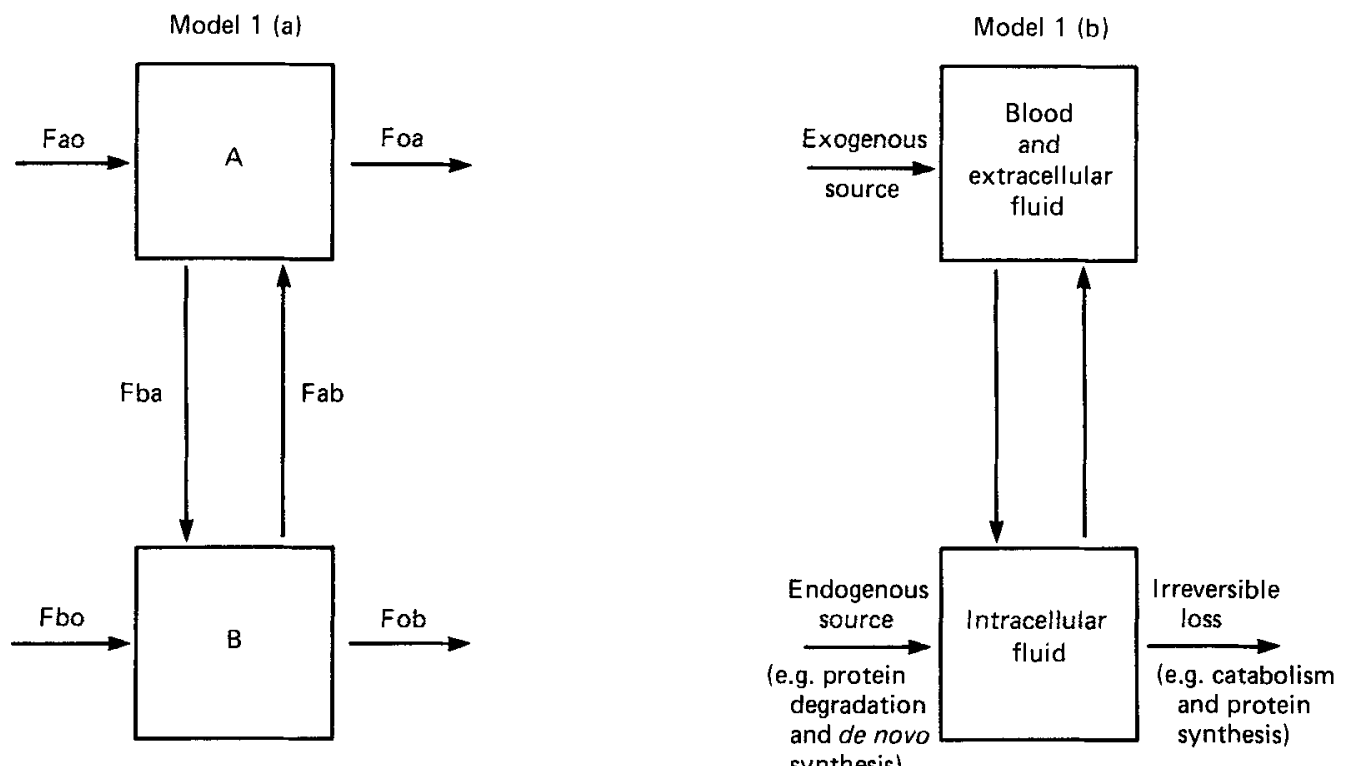

Model 1 (c)
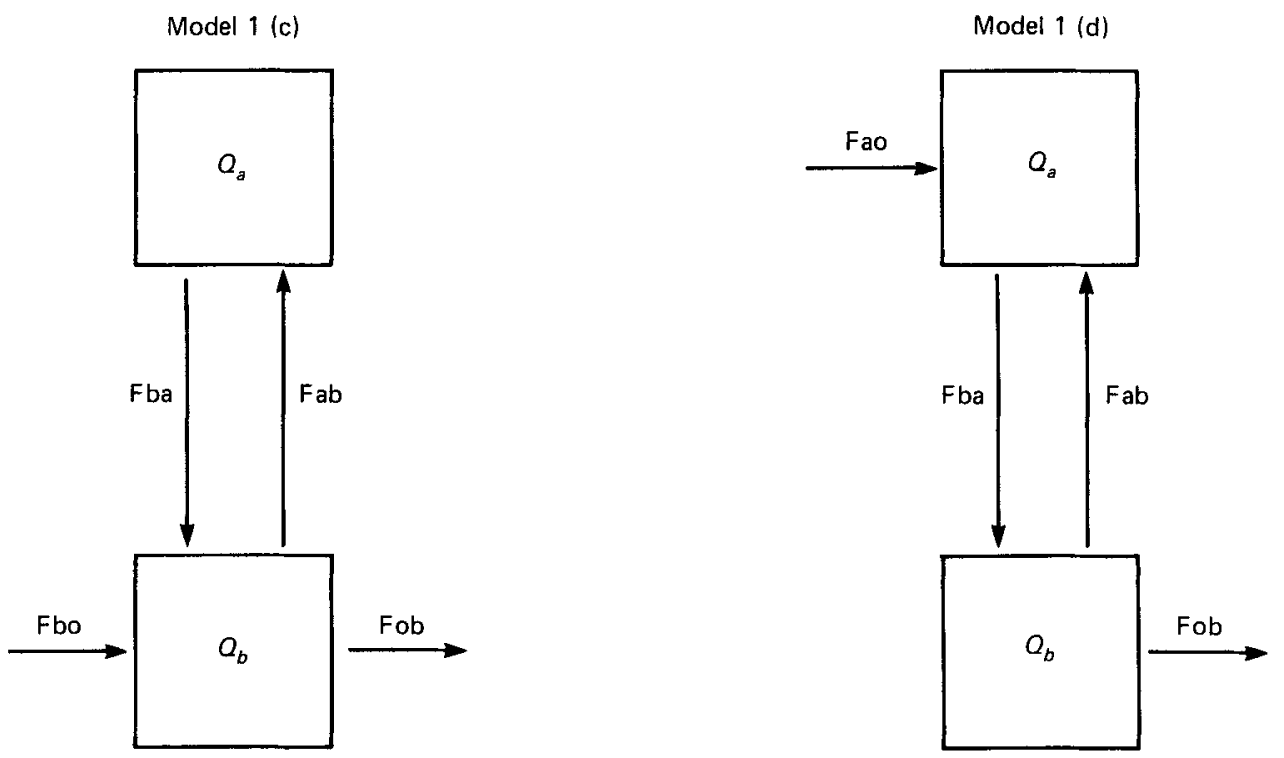

Fig. 1. Two-pool models of alanine and of glycine metabolism in lambs. Model 1(a), generalized model; model 1(b), physiological interpretation of model 1(a); model 1(c), model used to calculate the rate of irreversible loss of amino acid assuming no exogenous entry into pool $\mathbf{A}$; model $1(\mathrm{~d})$, model used to calculate the rate of irreversible loss of amino acid assuming an exogenous entry into pool A. 
Table 2. Glycine and alanine concentrations, packed cell volume, oxygen pressure $\left(p \mathrm{O}_{2}\right)$, carbon dioxide pressure $\left(\mathrm{pCO}_{2}\right)$ and $\mathrm{pH}$ in the blood of lambs during the isotope dilution experiments

(Linear regression lines have been fitted to the experimental points for the blood amino acid concentration and packed cell volume. Values for the start and end have been derived from these lines. The mean values are given with the no. of observations in parentheses)

\begin{tabular}{|c|c|c|c|c|c|c|c|}
\hline Experiment $\dagger$ & $\begin{array}{l}\text { Site of blood } \\
\text { sampling }\end{array}$ & & $\begin{array}{l}\text { Amino acid } \\
\text { concentration } \\
(\mu \mathrm{mol} / \mathrm{l})\end{array}$ & $\begin{array}{c}\text { Packed cell } \\
\text { volume }\end{array}$ & $\begin{array}{c}\mathrm{pO}_{2} \\
(\mathrm{~mm} \mathrm{Hg})\end{array}$ & $\begin{array}{c}\mathrm{pCO}_{2} \\
(\mathrm{~mm} \mathrm{Hg})\end{array}$ & $\mathrm{pH}$ \\
\hline \multirow[t]{4}{*}{ Gly 2} & Femoral artery & Start & 1126 & 0.41 & $19 \cdot 0$ & $54 \cdot 4$ & $7 \cdot 303$ \\
\hline & & End & $1061^{*}$ & $0 \cdot 35^{*}$ & $19 \cdot 4$ & $56 \cdot 2$ & $7 \cdot 303$ \\
\hline & & Mean & 1095 (13) & $0.38(12)$ & - & - & - \\
\hline & & $\mathrm{CV}(\%)$ & 2.9 & $8 \cdot 2$ & - & - & - \\
\hline \multirow[t]{4}{*}{ Gly 1} & Femoral artery & Start & 577 & 0.42 & $20 \cdot 0$ & $50 \cdot 0$ & $7 \cdot 341$ \\
\hline & & End & 513 & 0.41 & ND & ND & ND \\
\hline & & Mean & $556(11)$ & $0.42(6)$ & - & - & - \\
\hline & & $\mathrm{CV}(\%)$ & 11.9 & $5 \cdot 8$ & - & - & - \\
\hline \multirow[t]{4}{*}{ Gly 3} & Femoral artery & Start & 659 & 0.40 & ND & ND & ND \\
\hline & & End & 673 & $0.36^{*}$ & ND & ND & ND \\
\hline & & Mean & $665(14)$ & $0.38(12)$ & - & - & - \\
\hline & & $\mathrm{CV}(\%)$ & $3 \cdot 7$ & $4 \cdot 6$ & - & - & - \\
\hline \multirow[t]{4}{*}{ Gly 4} & Vena cava & Start & 601 & 0.36 & $15 \cdot 7$ & $47 \cdot 2$ & $7 \cdot 265$ \\
\hline & & End & $516^{* *}$ & $0 \cdot 34$ & $15 \cdot 7$ & $47 \cdot 4$ & $7 \cdot 304$ \\
\hline & & Mean & $576(13)$ & $0.36(13)$ & - & - & - \\
\hline & & $\mathrm{CV}(\%)$ & 5.9 & $4 \cdot 0$ & - & - & - \\
\hline \multirow[t]{4}{*}{ Gly 7} & Umbilical vein & Start & 750 & 0.31 & $41 \cdot 1$ & $38 \cdot 9$ & $7 \cdot 345$ \\
\hline & & End & 706 & $0 \cdot 30$ & $37 \cdot 5$ & 38.9 & $7 \cdot 403$ \\
\hline & & Mean & $738(11)$ & $0.31(11)$ & - & - & - \\
\hline & & $\mathrm{CV}(\%)$ & $10 \cdot 3$ & $4 \cdot 3$ & - & - & - \\
\hline \multirow[t]{4}{*}{ Gly 6} & Jugular vein & Start & 596 & ND & ND & ND & ND \\
\hline & & End & $367^{* * *}$ & ND & ND & ND & ND \\
\hline & & Mean & $532(13)$ & - & - & - & - \\
\hline & & $\mathrm{CV}(\%)$ & $14 \cdot 2$ & - & - & - & - \\
\hline \multirow[t]{4}{*}{ Ala 1} & Umbilical vein & Start & 284 & $0 \cdot 38$ & $55 \cdot 0$ & $51 \cdot 0$ & $7 \cdot 422$ \\
\hline & & End & 235 & 0.39 & $37 \cdot 3$ & 40.6 & $7 \cdot 435$ \\
\hline & & Mean & $272(9)$ & $0.39(6)$ & - & - & - \\
\hline & & $\mathrm{CV}(\%)$ & $14 \cdot 2$ & $3 \cdot 8$ & - & - & - \\
\hline \multirow[t]{4}{*}{ Ala 6} & Vena cava & Start & 210 & 0.41 & $22 \cdot 1$ & $52 \cdot 1$ & $7 \cdot 338$ \\
\hline & & End & 225 & 0.42 & 16.6 & $52 \cdot 6$ & $7 \cdot 344$ \\
\hline & & Mean & $213(11)$ & $0.41(6)$ & - & - & - \\
\hline & & $\mathrm{CV}(\%)$ & $10 \cdot 3$ & $1 \cdot 8$ & - & - & - \\
\hline \multirow[t]{4}{*}{ Ala 5} & Umbilical vein & Start & 282 & 0.35 & $37 \cdot 5$ & $38 \cdot 7$ & $7 \cdot 349$ \\
\hline & & End & $346^{*}$ & 0.39 & 40.9 & 35.9 & $7 \cdot 351$ \\
\hline & & Mean & $298(11)$ & $0.36(5)$ & - & - & - \\
\hline & & $\mathrm{CV}(\%)$ & $9 \cdot 6$ & $7 \cdot 5$ & - & - & - \\
\hline \multirow[t]{4}{*}{$\mathrm{Ala} 7$} & Umbilical vein & Start & 212 & $0 \cdot 38$ & $39 \cdot 5$ & $38 \cdot 8$ & $7 \cdot 345$ \\
\hline & & End & 165 & 0.37 & $28 \cdot 1$ & $42 \cdot 7$ & $7 \cdot 435$ \\
\hline & & Mean & $200(11)$ & $0 \cdot 38(5)$ & - & - & - \\
\hline & & $\mathrm{CV}(\%)$ & 13.9 & $5 \cdot 3$ & - & - & - \\
\hline \multirow[t]{4}{*}{ Ala 2} & Femoral artery & Start & 203 & 0.40 & $21 \cdot 8$ & $51 \cdot 2$ & $7 \cdot 347$ \\
\hline & & End & $247^{*}$ & 0.41 & $19 \cdot 1$ & $49 \cdot 5$ & $7 \cdot 369$ \\
\hline & & Mean & $214(13)$ & $0 \cdot 40(6)$ & - & - & - \\
\hline & & $\mathrm{CV}(\%)$ & $10 \cdot 1$ & $3 \cdot 1$ & - & - & - \\
\hline \multirow[t]{4}{*}{ Ala 4} & Jugular vein & Start & 223 & ND & ND & ND & ND \\
\hline & & End & $278^{*}$ & ND & ND & ND & ND \\
\hline & & Mean & 238 (13) & - & - & - & -- \\
\hline & & CV $(\%)$ & $13 \cdot 0$ & - & - & - & - \\
\hline \multirow[t]{4}{*}{ Ala 3} & Jugular vein & Start & 195 & ND & ND & ND & ND \\
\hline & & End & 262 & ND & ND & ND & ND \\
\hline & & Mean & 214 (13) & - & - & - & - \\
\hline & & $\mathrm{CV}(\%)$ & $19 \cdot 2$ & - & - & - & - \\
\hline
\end{tabular}

ND, not determined; $\mathrm{CV}$, coefficient of variation (the standard deviation expressed as a percentage of the mean value). Value was significantly different from starting value: ${ }^{*} P<0.05,{ }^{* *} P<0.01,{ }^{* * *} P<0.001$.

† For details, see Table 1. 
of the fetuses, the fetal component of the placenta. If pool A is considered as consisting of the blood and extracellular fluid then it is unlikely that extensive metabolism of the amino acids occurs within this pool and hence exit of metabolites from pool A can only be into tissues (Fba) and therefore Foa may be considered to be zero. The flow, Fao, into pool A must be considered to be an input from an exogenous source which in the fetus may be considered to be the direct transfer of metabolites from mother to fetus and, in the sucking lamb, may be considered to be the direct transfer of metabolites from the gut lumen into the portal circulation. The flow, Fob, out of pool B represents the irreversible loss of the amino acids during the course of the experiment and for an amino acid this will include protein synthesis and conversion to other metabolites including $\mathrm{CO}_{2}$. The flow, Fbo, into pool B represents the endogenous generation of the metabolite which in the case of an amino acid may result from protein degradation and de novo synthesis. Fba and Fab represent the exchange between the intracellular fluids and extracellular fluids which include blood. Model 1 (a) may therefore be interpreted physiologically as set out in model 1(b) (Fig. 1).

Analysis of the specific activity $v$. time curve yields two exponential functions from which two flux-rates may be derived assuming that the pool sizes remain constant during the course of the experiment. Therefore in setting limits to our model we have assumed that either Fao is zero (see model 1(c)) or that Fbo is zero (see model 1(d)) (Fig. 1). In model 1(c) it is evident that in the steady-state Fbo is equal to Fob and Fba is equal to Fab, hence the four flux-rates may be ascribed values deduced from the two exponential terms. In model 1 (d) it is evident that in the steady-state Fao is equal to Fob and that Fab is equal to $\mathrm{Fba}-\mathrm{Fao}$. Again there are only two unknowns which can be solved. The amalgamation of models 1 (c) and 1 (d) yields the composite model 1 (b) to which maximum and minimum limits for the fluxes may be set. The models 1 (c) and 1 (d) correspond to model $\mathrm{C}$ and to model A respectively as illustrated by Shipley \& Clark (1972, Fig. 18). The fluxes Fao and Fob in model 1(d) may be compared directly with the irreversible loss obtained by a stochastic approach (Katz et al. 1974).

No models have been derived for the results obtained in the two experiments in which the radioactive glycine was infused continuously. The irreversible loss of glycine determined in these two experiments is equivalent to the flow, Fob, out of pool B in the two-pool model $1(\mathrm{~d})$.

\section{RESULTS}

The mean concentration of glycine and of alanine and the mean packed cell volumes obtained during the course of the isotope dilution experiments are given in Table 2. Regression lines were fitted to the experimental points for each animal in order to determine whether or not any significant changes occurred in the concentration of glycine or of alanine during the course of the experiment. The values given in Table 2 for the start and end of the experimental period have been derived from regression lines and they are not the actual values for the sample taken. In some animals significant changes in blood amino acid concentrations were observed but no consistent directional change between animals was evident for either glycine or alanine. No significant changes were found in blood packed cell volumes during the course of the single injection experiments but in the two fetuses into which glycine was infused continuously the packed cell volumes declined. The values for the $\mathrm{pO}_{2}, \mathrm{pCO}_{2}$ and $\mathrm{pH}$ for samples of blood taken at the start and the end of the experiments are also given in Table 2 . No radioactivity was detected in alanine or glycine in uterine venous blood during the course of the radioisotope dilution experiments.

The equations describing normalized curves relating specific activities of the amino acids in blood and time during the course of the isotope-dilution experiments are given in Table 3 together with the probability of goodness of fit. The values have been normalized such 


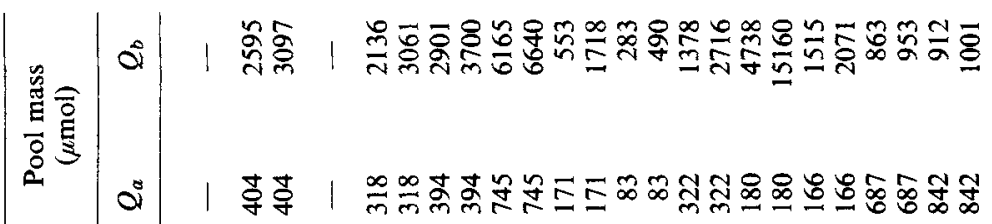
总这初

要远

용

E

.

要过

政

可

象

施

急.

$F . \frac{9}{5}$

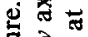

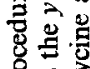

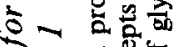

的客家

亏

을

ธิ

है कै

$\rightarrow$ ष

고

ไิ

ठ․

ठำ

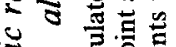

乐

芩

s

论

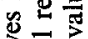

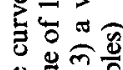

政

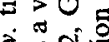

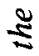

$\therefore$ 政 $\mathrm{i}$.

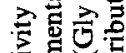

.

을

氜

产.

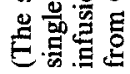

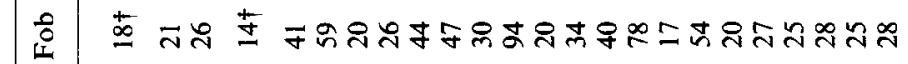

在 | O OR

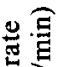

层总

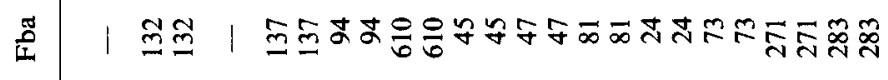

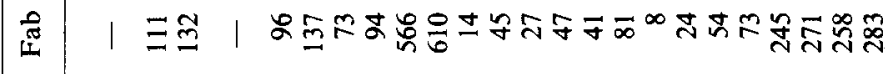

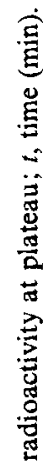

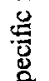

a

II 1 n० 1 7.

$\stackrel{\ddot{E}}{\mathrm{E}}$

递

$\frac{\bar{d}}{\overline{0}}$

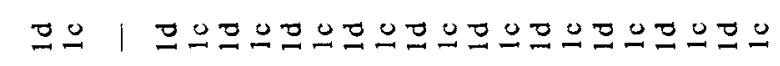

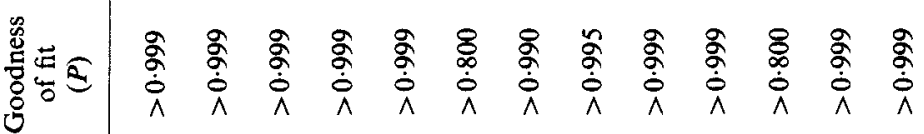

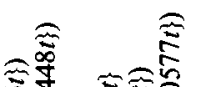

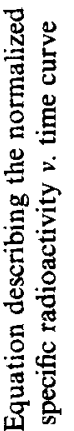

害守

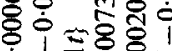

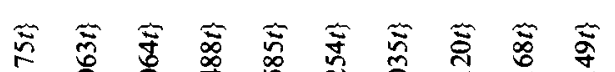

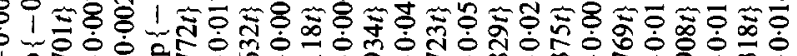

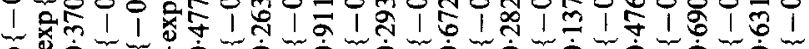

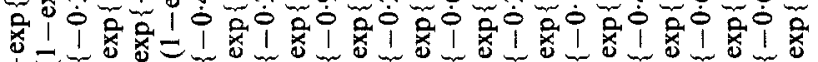

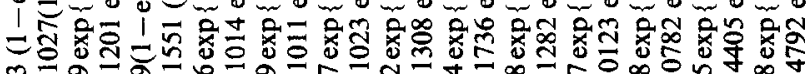

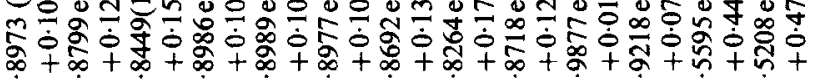

||

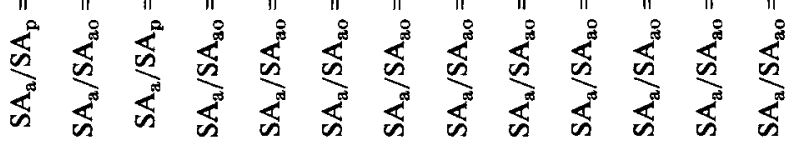

营 
Table 4. Percentage of carbon dioxide in blood derived from either glycine or alanine in fetal and sucking lambs

(The percentage of $\mathrm{CO}_{2}$ derived from either alanine or glycine was calculated using eqn (2c), p. 97, Shipley \& Clark (1972))

\begin{tabular}{ccc}
\hline \hline & $\begin{array}{c}\text { Percentage of } \mathrm{CO}_{2} \\
\text { from amino acid }\end{array}$ \\
\hline Gly 2 & 0.03 \\
Gly 1 & 0.25 \\
Gly 3 & 0.05 \\
Gly 4 & 0.16 \\
Gly 7 & 0.09 \\
Gly 6 & 0.25 \\
Ala 1 & 2.09 \\
Ala 6 & 0.97 \\
Ala 5 & 1.07 \\
Ala 7 & 0.24 \\
Ala 2 & 0.41 \\
Ala 4 & 1.61 \\
Ala 3 & 0.94 \\
\hline \hline
\end{tabular}

* For details, see Table 1.

that for the single-injection experiments a value of 1 represents the point at which the extrapolated curve intercepts the $y$ axis (i.e. zero time). In the case of the two constant infusion experiments (Gly 2, Gly 3) a value of 1 represents the calculated specific radioactivity of glycine at the 'true' plateau. Flux rates and pool masses for glycine and alanine in the individual animals are also shown in Table 3.

The irreversible losses of glycine in the fetal lambs into which the radioisotope was infused continuously (Gly 2, Gly 3 ) were 15 and $10 \mu \mathrm{mol} / \mathrm{min}$ per $\mathrm{kg}$ respectively. The mean irreversible loss of glycine in the three fetal lambs into which the radioisotope was administered as a single injection was found to be 17 (SE 5.7) $\mu \mathrm{mol} / \mathrm{min}$ per $\mathrm{kg}$ when model 1 (d) was assumed. Since flux, Fob, in model 1 (d) may be equated with the irreversible loss obtained by a stochastic approach the results from the single injection experiments and the continuous infusion experiments may be considered together and hence the mean irreversible loss of glycine in the five fetal lambs was 15 (SE 3.4) $\mu \mathrm{mol} / \mathrm{min}$ per $\mathrm{kg}$. However, if the irreversible loss of glycine is derived assuming model 1 (c), then the mean irreversible loss of glycine in the three fetal lambs was 23 (SE 8.6) $\mu \mathrm{mol} / \mathrm{min}$ per $\mathrm{kg}$, a value which was somewhat higher than that calculated assuming model 1 (d). For the sucking lamb similar values for the irreversible loss of glycine were obtained irrespective of the model assumed, these were $11 \mu \mathrm{mol} / \mathrm{min}$ per $\mathrm{kg}$ for model 1 (d) and $12 \mu \mathrm{mol} / \mathrm{min}$ per $\mathrm{kg}$ for model 1 (c).

For alanine the mean rate of irreversible loss in the five fetal lambs represented by the flux, Fob, in model 1(d) was 14 (SE $2 \cdot 6$ ) $\mu \mathrm{mol} / \mathrm{min}$ per $\mathrm{kg}$. This value was significantly lower $(P=0.05$, Student's paired $t$ test) than that derived assuming model 1 (c) which was 32 (SE $8.2) \mu \mathrm{mol} / \mathrm{min}$ per $\mathrm{kg}$. In the two sucking lambs the rates of irreversible loss of alanine were similar irrespective of the model assumed; these were 6.8 and $7.6 \mu \mathrm{mol} / \mathrm{min}$ per $\mathrm{kg}$ for models 1(d) and 1(c) respectively in lamb Ala 4 and in the other sucking lamb (Ala 3) the values were 3.65 and $3.9 \mu \mathrm{mol} / \mathrm{min}$ per $\mathrm{kg}$.

$\mathrm{CO}_{2}$ in fetal blood was found to be radioactive after the administration of the labelled amino acids indicating that there was some oxidation of the amino acids to $\mathrm{CO}_{2}$. Radioactively labelled $\mathrm{CO}_{2}$ was also detected in uterine venous blood but the specific activity 
Table 5. Concentration of glycine and of alanine in blood from maternal and fetal sheep during the period from 102 to 129 d after conception

(Results are mean values with their standard errors; nos. of animals sampled given in parentheses. The value for any one animal was the mean of samples of blood taken on several days at 10.00 hours during the period)

\begin{tabular}{|c|c|c|c|c|}
\hline \multirow[b]{3}{*}{ Source of blood } & \multicolumn{4}{|c|}{ Amino acid concentration $(\mu \mathrm{mol} / \mathrm{l})$} \\
\hline & \multicolumn{2}{|c|}{ Glycine } & \multicolumn{2}{|c|}{ Alanine } \\
\hline & Mean & SE & Mean & SE \\
\hline Maternal jugular vein & 677 & $36(12)$ & 151 & $12(14)$ \\
\hline Maternal uterine vein & 710 & $58(5)$ & 159 & $20(7)$ \\
\hline Fetal femoral artery (umbilical artery) & 755 & $31(9)$ & 229 & $32(10)$ \\
\hline Umbilical vein & 698 & $41(5)$ & 255 & $25(6)$ \\
\hline Fetal posterior vena cava & 654 & $43(5)$ & 195 & $15(6)$ \\
\hline
\end{tabular}

was very much lower than that in fetal blood. From this it may be concluded that oxidation of $\left[\mathrm{U}^{14} \mathrm{C}\right] \mathrm{alanine}$ and $\left[\mathrm{U}_{-}{ }^{14} \mathrm{C}\right] \mathrm{glycine}$ occurred in fetal tissues. The relationship between the irreversible losses of glycine and of alanine and $\mathrm{CO}_{2}$ are summarized in Table 4. In fetal lambs 0.96 (SE 0.32$) \%$ of the $\mathrm{CO}_{2}$ present in blood was derived from alanine and only 0.12 (SE 0.04$) \%$ was derived from glycine.

Samples of blood were obtained from the ewes and fetuses not only during the isotope-dilution experiments but also on other days during the period from 102 to $129 \mathrm{~d}$ after conception. The mean concentrations of glycine and of alanine in maternal venous blood and in fetal blood during this period are given in Table 5. Maternal and fetal blood glycine concentrations were similar. Fetal blood alanine concentrations were consistently greater than those in maternal blood.

\section{DISCUSSION}

The values given for the concentrations of glycine and of alanine in maternal and fetal blood are similar to those reported by others (Lemons et al. 1976; Holzman et al. 1979). The present results indicate that glycine is not released into the fetal circulation from the placenta although a significant umbilical venous-arterial difference for glycine of $28 \mu \mathrm{mol} / 1$ has been reported (Lemons et al. 1976). However, the mean umbilical venous-arterial difference for alanine of $26 \mu \mathrm{mol} / 1$ is similar to that of $23 \mu \mathrm{mol} / 1$ reported for fetuses of mean age $130 \mathrm{~d}$ (Lemons et al. 1976).

In the analysis of the results from the radioisotope-dilution experiments it was assumed that the tracer uniformly labelled the inflow of tracee and that steady-state conditions existed. In fetal and sucking lambs a steady-state condition cannot exist in view of the accumulation of free amino acids that occurs in growing animals. However, since the time-course of the experiments never exceeded $6 \mathrm{~h}$ the increase in body-weight during this period was less than $1 \%$ and hence the error due to this must be slight. The concentrations of the amino acids in blood of individual animals were not always constant during the timecourse of the experiments. However, on average the concentration of glycine in blood declined by $11 \%$ during the experimental period and the concentration of alanine increased by $9 \%$ but neither of these changes were significant $(P>0.05)$. 
The values obtained for the irreversible loss (Fob) of the amino acids assuming model 1 (d) may be compared with published values for the irreversible losses obtained by a stochastic analysis. The mean irreversible loss of alanine in fetal lambs of $14 \mu \mathrm{mol} / \mathrm{min}$ per $\mathrm{kg}$, although lower than the mean value of $24 \mu \mathrm{mol} / \mathrm{min}$ per $\mathrm{kg}$ determined by Prior \& Christenson (1977) using the continuous-infusion technique, is not outside the $95 \%$ confidence interval for their mean value. At 1 week following birth the mean irreversible loss of alanine declined to $5.1 \mu \mathrm{mol} / \mathrm{min}$ per $\mathrm{kg}$ (model 1 (d)) and this value tends to be greater than the values of $1.0 \mu \mathrm{mol} / \mathrm{min}$ per $\mathrm{kg}$ for ewe lambs of mean weight $37 \mathrm{~kg}$ (Prior $\&$ Christenson, 1977) and 3.7 $\mu \mathrm{mol} / \mathrm{min}$ per $\mathrm{kg}$ for mature sheep (Wolff \& Bergman, 1972). The mean rates of irreversible loss of glycine in the fetuses $(15 \mu \mathrm{mol} / \mathrm{min}$ per $\mathrm{kg})$ and in the sucking lamb $(11 \mu \mathrm{mol} / \mathrm{min}$ per $\mathrm{kg})$ were also greater than the value of $4.9 \mu \mathrm{mol} / \mathrm{min}$ per kg for mature sheep (Wolff \& Bergman, 1972).

When comparing values for animals of widely differing body-weights a more appropriate way of expressing the results may be as a function of metabolic body size (i.e. body-weight ${ }^{\cdot \cdot 75}$ ). When the values for the irreversible loss of the amino acids derived from model 1 (d) were expressed in this manner and considered together with those of Wolff \& Bergman (1972), the rates of irreversible loss of glycine were 17,16 and $13 \mu \mathrm{mol} / \mathrm{min}$ per $\mathrm{kg}$ body-weight $\mathrm{t}^{0.75}$ for fetal lambs, for the sucking lamb and for mature ewes respectively. Similarly, the rates of irreversible loss of alanine were 16,8 and $10 \mu \mathrm{mol} / \mathrm{min}$ per $\mathrm{kg}$ body-weight ${ }^{\cdot \cdot 75}$ for fetal lambs, sucking lambs and mature ewes respectively. It would appear that there were no substantial differences in the rates of turnover of either alanine or glycine as the lambs mature when these rates, calculated assuming a stochastic or catenary model, are expressed as a function of metabolic body size. These values are of the same order of magnitude as the rates of glycine and alanine turnover in post-absorptive young men weighing $70 \mathrm{~kg}$, i.e. 12 and $17 \mu \mathrm{mol} / \mathrm{min}$ per $\mathrm{kg}$ body-weight $\mathrm{t}^{0.75}$ respectively (Young, 1981).

It appears that the metabolism of alanine and of glycine together contribute to approximately $1 \%$ of the blood $\mathrm{CO}_{2}$ (including bicarbonate) in the fetal lambs. If the rate of $\mathrm{CO}_{2}$ loss by the fetal lamb is assumed to be $252 \mu \mathrm{mol} / \mathrm{min}$ per $\mathrm{kg}$ (Battaglia \& Meschia, 1973), then the rates of amino acid catabolism to $\mathrm{CO}_{2}$ may be estimated. In the fetal lamb the mean rate for alanine is $0.8 \mu \mathrm{mol} / \mathrm{min}$ per $\mathrm{kg}$ and for glycine $0.15 \mu \mathrm{mol} / \mathrm{min}$ per $\mathrm{kg}$. When the variance of the values is considered it is apparent that not more than $1.6 \mu \mathrm{mol}$ alanine $/ \mathrm{min}$ per $\mathrm{kg}$ and $0.29 \mu \mathrm{mol}$ glycine $/ \mathrm{min}$ per $\mathrm{kg}$ could have been converted to $\mathrm{CO}_{2}$ $(P=0.05)$.

The stochastic approach to analysis of the results obtained from experiments involving isotope dilution in whole animals has been advocated (Katz et al. 1974) and this approach has been widely used in the investigation of ruminant metabolism. Additional information can be obtained from this type of experiment using analytical procedures set out by Shipley \& Clark (1972). Such information includes pool sizes, rates of interchange between the pools and an alternative estimate of the irreversible loss based on an assumption that the entry of metabolite is not directly into the sampling pool but through a second pool.

The two models 1 (c) and 1 (d) yield similar values for the irreversible loss (Fob) of alanine and of glycine and for the pool masses of pool B $\left(Q_{b}\right)$ in the sucking lambs. However, when the metabolism of alanine and of glycine is considered in the fetuses differences in Fob and $Q_{b}$ were found when different models were assumed. For alanine there was a $130 \%$ increase in the irreversible loss (Fob) when model 1(c) was assumed compared with model 1(d); similarly, in the case of glycine a $35 \%$ increase in the irreversible loss was apparent. In interpreting model 1 (d) we have assumed that the entry of amino acid into pool A (the pool sampled which includes blood) is from an exogenous source whereas in model 1 (c) we have assumed that the entry of the amino acid into the blood is indirect and results from metabolism within a second pool, B, the tissues. In the fetus the true situation may lie 
between these two extremes. Therefore the two values obtained for Fob for each of the amino acids may be considered as representing upper and lower estimates for the irreversible loss.

In considering the metabolism of glycine in the sheep fetus the upper estimate of the irreversible loss (Fob, $23 \mu \mathrm{mol} / \mathrm{min}$ per $\mathrm{kg}$ ) derived from model 1 (c) may be regarded as the most realistic since there is a negligible uptake of glycine from the uterine circulation (Holzman et al. 1979; Morriss et al. 1979) and therefore there is no entry of glycine into pool A from an exogenous source. Glycine present in fetal blood must be derived from metabolism within fetal tissues and glycine will enter the blood by way of the tissues (pool B).

It is possible to obtain a maximum estimate of the rate of protein synthesis in the whole animal from a knowledge of the amino acid content of body protein and from the value for the irreversible loss of an amino acid corrected for loss due to metabolism by way of other pathways such as complete oxidation to $\mathrm{CO}_{2}$. The extent of protein synthesis and turnover in fetal lambs can be estimated from a consideration of our values for glycine. The amount of glycine converted to $\mathrm{CO}_{2}$ would appear to be small and may be disregarded. Thus the maximum amount of glycine which could be incorporated into protein is $23 \mu \mathrm{mol} / \mathrm{min}$ per $\mathrm{kg}$ and this is equivalent to $2.5 \mathrm{~g}$ glycine incorporated into protein $/ \mathrm{d}$ per $\mathrm{kg}$. Assuming that the glycine content of whole-body protein in fetal lambs aged between 106 and $120 \mathrm{~d}$ is $92 \mathrm{~g} / \mathrm{kg}$ protein (F. C. Battaglia, personal communication), then the amount of protein synthesized cannot exceed $27 \mathrm{~g} / \mathrm{d}$ per $\mathrm{kg}$. This rate of protein synthesis may be compared with an estimate of the rate of crude protein accretion in fetal lambs of similar age. From the growth rate of the lambs (see equation, p. 000) and carcass composition (McDonald et al. 1979) it can be calculated that the rate of crude protein accretion is approximately $6.5 \mathrm{~g} / \mathrm{d}$ per kg. Thus it is evident that approximately $24 \%$ of the protein synthesized is retained. The rate of protein degradation may therefore be $20.5 \mathrm{~g}$ protein $/ \mathrm{d}$ per $\mathrm{kg}$. This rate of protein degradation can be expected to result in the release of $17.5 \mu \mathrm{mol}$ glycine $/ \mathrm{min}$ per $\mathrm{kg}$. The difference between the irreversible loss of glycine and the rate of release of glycine from protein is $5.5 \mu \mathrm{mol} / \mathrm{min}$ per $\mathrm{kg}$. Since no glycine is derived from the maternal circulation this value is an estimate of the rate of glycine synthesis by fetal tissues. The rate of protein synthesis calculated from the values for glycine may be compared with the mean value of $16.8 \mathrm{~g} / \mathrm{d}$ per $\mathrm{kg}$ in five fetal lambs aged between 110 and $125 \mathrm{~d}$ which was calculated from the lysine specific activity ratio, carcass:plasma (Meier et al. 1981) and with the value of $38.6 \mathrm{~g} / \mathrm{d}$ per $\mathrm{kg}$ for six fetal lambs aged between 123 and $130 \mathrm{~d}$ calculated from the total flux of lysine in blood assuming that all the amino acid leaving the circulation entered protein and neglecting that which is oxidized (Noakes \& Young, 1981).

Alanine metabolism in fetal lambs may be evaluated further. The rate of entry of alanine into pool A from an exogenous source (Fao) may be estimated from a consideration of uterine and umbilical arterio-venous differences for alanine and blood flows. It would appear that alanine released into the umbilical circulation from the placenta is derived by direct transfer from maternal blood (Holzman et al. 1979). If the umbilical venous-arterial difference for alanine is $26 \mu \mathrm{mol} / 1$ (present study) and the umbilical blood flow is taken to be $168 \mathrm{ml} / \mathrm{min}$ per $\mathrm{kg}$ (Lemons et al. 1976) we conclude that alanine is released into the fetal circulation from the placenta at $4.4 \mu \mathrm{mol} / \mathrm{min}$ per $\mathrm{kg}$.

Our calculations derived from the results of the isotope dilution experiments predict that the rate of alanine entry into pool A from an exogenous source (Fao) is either zero (model $1(\mathrm{c})$ ) or is equal to the rate of irreversible loss (Fob) given by model 1(d) which was $14 \mu \mathrm{mol} / \mathrm{min}$ per $\mathrm{kg}$. It would appear therefore that in fact the entry into pool A (Fao) lies between these values. There must also be an entry of alanine into pool B (Fbo) other than from pool A which will consist of two components: alanine released as the result of 
protein degradation and alanine formed by way of transamination of pyruvate since there is appreciable activity of alanine aminotransferase $(E C$ 2.6.1.2) in tissues of fetal lambs (Edwards et al. 1975). Since the alanine content of mixed body protein in fetal lambs is $63 \mathrm{~g} / \mathrm{kg}$ protein (F.C. Battaglia, personal communication), and the rate of protein degradation in fetal lambs may be $20.5 \mathrm{~g} / \mathrm{d}$ per kg, the rate of alanine released as the result of protein degradation will be $10 \mu \mathrm{mol} / \mathrm{min}$ per $\mathrm{kg}$ and hence the flux Fbo is unlikely to be less than this value. Model 1(c) assumes that all of the entry of alanine into the system is by way of pool B (Fbo) and that the irreversible loss of alanine (Fob) will be equal to this rate $(32 \mu \mathrm{mol} / \mathrm{min}$ per $\mathrm{kg})$ whereas model 1 (d) assumes that the flux Fbo is zero. It would appear that in fact the rate of entry of alanine into pool B (Fbo) lies between these values. Clearly neither the catenary model, $1(\mathrm{~d})$, nor model 1 (c) adequately describe the flux of alanine in fetal lambs. The model which describes alanine flux best is the composite model 1(b) in which the irreversible loss must lie between the values predicted for model 1 (c) and model 1(d), that is between 14 and $32 \mu \mathrm{mol} / \mathrm{min}$ per $\mathrm{kg}$. It may be concluded that calculations of the irreversible loss of alanine in fetal lambs based on either a catenary model or on a lumped pool system may result in an underestimate of this value. However, in sucking lambs both models predict similar rates for the pool mass $\left(Q_{b}\right)$ and for the irreversible loss (Fob). The difference between fetal and sucking lambs may be related to the fact that in fetuses a continual supply of alanine enters the circulation by direct transfer from the maternal circulation.

This investigation was supported by a grant from the Agricultural and Food Research Council. G.M.H. was the recipient of a postgraduate studentship from the Ministry of Agriculture, Fisheries and Food.

The authors thank Mr I. A. N. Wilson, of the Grassland Research Institute, Hurley, Berks, who carried out the radiological examination of the pregnant ewes.

\section{REFEREN CES}

Agricultural Research Council (1965). The Nutrient Requirements of Farm Livestock, no. 2. Ruminants. London: Agricultural Research Council.

Battaglia, F. C. \& Meschia, G. (1973). In Foetal and Neonatal Physiology, pp. 382-397 [R. S. Comline, K. W. Cross, G. S. Dawes and P. W. Nathanielsz, editors]. Cambridge: Cambridge University Press.

Bergman, E. N. (1963). American Journal of Physiology 204, 147-152.

Edwards, E. M., Dhand, U. K., Jeacock, M. K. \& Shepherd, D. A. L. (1975). Biochimica et Biophysica Acta 399, $217-227$.

Egan, A. R. \& MacRae, J. C. (1979). Annales de Recherches Veterinaires 10, 376-378.

Gresham, E. L., James, E. J., Raye, J. C., Battaglia, F. C., Makowski, E. L. \& Meschia, G. (1972). Pediatrics, Springfield 50, 372-379.

Haworth, C. \& Heathcote, J. G. (1969). Journal of Chromatography 41, 380-385.

Heitman, R. N., Hoover, W. H. \& Sniffen, C. J. (1973). Journal of Nutrition 103, 1587-1593.

Hinks, N. T., Mills, S. C. \& Setchell, B. P. (1966). Analytical Biochemistry 17, 551-553.

Hodgson, J. C., Mellor, D. J. \& Field, A. C. (1980). Biochemical Journal 186, 739-747.

Holzman, I. R., Lemons, J. A., Meschia, G. \& Battaglia, F. C. (1979). Journal of Developmental Physiology 1, $137-149$.

Katz, J., Rostami, H. \& Dunn, A. (1974). Biochemical Journal 142, 161-170.

Lemons, J. A., Adcock, E. W., Jones, M. D., Naughton, M. A., Meschia, G. \& Battaglia, F. C. (1976). Journal of Clinical Investigation 58, 1428-1434.

McDonald, I., Robinson, J. J., Fraser, C. \& Smart, R. I. (1979). Journal of Agricultural Science, Cambridge 92, 591-603.

Meier, P. R., Peterson, R. G., Bonds, D. R., Meschia, G. \& Battaglia, F. C. (1981). American Journal of Physiology 240, E320-E324.

Meschia, G., Makowski, E. L. \& Battaglia, F. C. (1969). Yale Journal of Biology and Medicine 42, $154-165$.

Ministry of Agriculture, Fisheries and Food (1975). Energy Allowances and Feeding Systems for Ruminants. Technical Bulletin no. 33. London: H.M. Stationery Office.

Morriss, F. H., Adcock, E. W., Paxson, C. L. \& Greeley, W. J. (1979). American Journal of Obstetrics and Gynecology 135, 601-608. 
Noakes, D. E. \& Young, M. (1981). Research in Veterinary Science 31, 336-341.

Numerical Algorithms Group (1975). Fortran Library Manual, vol. 1, pp. 1-9, Nagflib 1265/187, Mk5. Oxford: NAG.

Ottaway, J. H. (1973). Biochemical Journal 134, 729-736.

Prior, R. L. \& Christenson, R. K. (1977). American Journal of Physiology 283, E462-E468.

Rattenbury, J. M., Jeacock, M. K. \& Shepherd, D. A. L. (1980). Biochimica et Biophysica Acta 630, $210-219$.

Redgwell, R. J., Turner, N. A. \& Bieleski, P. L. (1974). Journal of Chromatography 88, 25-31.

Sardesai, V. M. \& Provido, H. S. (1970). Clinica Chimica Acta 29, 67-71.

Schepartz, B. (1973). Regulation of Amino Acid Metabolism in Mammals. Philadelphia: W. B. Saunders \& Co.

Shipley, R. A. \& Clark, R. E. (1972). Tracer Methods for In Vivo Kinetics. New York and London: Academic Press.

Waterlow, J. C., Garlick, P. J. \& Millward, D. J. (1978). Protein Turnover in Mammalian Tissues and in the Whole Body. Amsterdam: North Holland Publishing Co.

Williamson, D. H. (1974). In Methods of Enzymatic Analysis, vol. 4, pp. 1679-1682 [H. U. Bergmeyer, editor]. New York: Academic Press.

Wolff, J. E. \& Bergman, E. N. (1972). American Journal of Physiology 223, 447-454.

Young, V. R. (1981). Proceedings of the Nutrition Society 40, 343-359. 